\title{
Humanistin teemojen tuntumassa
}

Urpo Harvan juhlakirja toim. Eeva Manni \& Jukka Tuomisto

Acta Universitatis Tamperensis ser A vol 196, Tampere 1985, $220 \mathrm{~s}$.

Emeritus professori Urpo Harvasta muodostuva kuva tämän kirjan perusteella ei ole kaikinpuolinen. Kuvassa on ulottuvuuksia eri suuntiin, mutta keskeisin ulottuvuus, syvyys, puuttuu. Teoksessa liikutaan Urpo Harvan teemojen tuntumassa, mutta humanismin juuriin ei kaivauduta.

Kirjassa on kolme keskeistä teemaa - arvofilosofiset peruskysymykset, yhteiskunnallinen uudistustyö ja siihen liittyvät arvokysymykset sekä aikuiskasvatuksen käytännön ja teorian kysymykset.

Arvofilosofisista peruskysymyksistä on kolme kirjoitusta. Raili Kauppi kirjoittaa "Arvoista ja ideaaleista filosofisessa antropologiassa" ja Sven Krohn aiheesta "Henkinen ihmiskäsitys. Aate ja kokemus". Kaupin ja Krohnin näkemykset täydentävät kiinnostavalla tavalla toisiaan. Siinä missä Kauppi asettaa arvojen (myös ihmisen itseisarvona) olemistavan ideaalikseksi samoin kuin käsitteelliset ja matemaattiset oliot, 
Krohn taas etsii "ydinihmistä', jonka filosofinen perusta on viimekädessä Krohnin omassa erityiskokemuksessa. Platonilaisen idealismin perinne elää näissä kirjoituksissa. Harvan tematiikan kannalta ehkä kiinnostavaa, mutta kontrasti "platonismille" puuttuu ja näin teemassa ei päästä kovin syvälle.

Arvo Oksasen artikkelissa "'Totta ja oikeaa", pohditaan tietoyhteiskuntaa ja siihen liittyvää tiedon ongelmaa kolmen myytin (tiedon puu, Prometheus, Faust) valossa. Myytit varoittavat meitä hämärästä - järjen valo ei riitä monimutkaistuvien tietokokonaisuuksien hallintaan. Traaginen näkemys irrationalismin voitosta voi antaa kontrastia sivistysideaalien puolustajille, mutta eikö aineksia realistiseen optimismiin ole myös olemassa. Ovathan ihmisen mahdollisuudet samalla kasvaneet ennennäkemättömiin mittoihin. Tiedon käytölle on avautunut aivan uusia ulottuvuuksia.

Kirjan toisesta teemasta, yhteiskunnallisesta uudistustyöstä ja siihen liittyvistä arvokysymyksistä, kirjoittivat Pekka Kuusi, V.O. Veilahti, Kauko Honkala ja Yrjö Littunen. Verrattuna filosofian teemaan, ote on Harvaan nähden suorempi ja kriittisempi. Erityisen kiinnostava on Pekka Kuusen artikkeli "Urpo Harva ja humanismin tavoitteleminen', Kuusen "60-luvun sosiaalipolitiikka" (1961) sai Harvalta "tuiman" kritiikin teoksessa "Ihminen hyvinvointivaltiossa"' (1964) ja toisaalta Kuusen "'Ihmisen maailma" ja Harvan "Inhimillinen ihminen" syntyivät samoihin aikoihin 1980-luvun alkuvuosina. Vaikka Kuusen ja Harvan näkemykset ovat edelleen kaukana toisistaan, niiden välinen suhde on kehittynyt. Kuusen näkemys on muuttunut ehkä enemmän ja rohkeammin, mikä pitkälti selittynee hänen läheisestä suhteestaan empiirisiin tieteisiin ja yhteiskunnalliseen pää- töksentekoon. Harvan näkemys ''ikuisista arvoista"' ei ole niin helposti muokkautuva. Siinä missä Kuusi nykyään rakentaa humanismia luonnontieteelliselle perustalle, Harva edelleen on filosofisen antropologian kannalla. Kummankaan humanismi ei suoranaisesti ponnista ihmisen yhteiskunnallisuuden ajatuksesta ja siitä, että ihmisen olemus ei ehkä olekaan annettu antropologisessa tai biologisessa mielessä, vaan on yhteiskunnallisesti muuttuva kokonaisuus.

Kirjan kolmas teema liittyy aikuiskasvatuksen käytännön ja teorian kehittämiseen. Teeman käsittely on luontevasti laajin, kirjoittajia on yhteensä kymmenen ja alateemoina ovat aikuiskasvatuksen käytännön kehittyminen (Kosti Huuhka, Olavi Alkio, M.O. Karttunen, Juha Sihvonen), aikuiskasvattajan tehtävä (Aulis Alanen, Helena Kekkonen, Ritva Jakku-Sihvonen) sekä Aikuiskasvatuksen tutkimus ja kehittäminen (Jukka Tuomisto, Eero Pantzar, Tero Autio).

Teoreettisesti kiinnostavia ovat Juha Sihvosen "Vapaa sivistystyö ja valtio"' sekä Aulis Alasen "Tehokas palvelu aikuiskasvattajan ammattiideaaalina". Molemmissa kirjoituksissa lähtökohtana ovat Max Weberin ajatukset. Sihvonen pyrkii osoittamaan vapaan sivistystyön perinteisen autonomian olevan vaarassa valtiollisen byrokratian saadessa "omaa tahtoa". Sihvosen mukaan vapaan sivistystyön autonomian "pahin uhka on... pitkälle byrokratisoitunut valtiollinen hallintokoneisto, jonka holhoava ote tiukkenee jatkuvasti." (130) Tästä ovat esimerkkeinä valtionosuusjärjestelmän muuttaminen menoperusteisesta suoriteperusteiseksi ja toiseksi se tapa, jolla kansalais- ja työväenopistoja kohdeltiin uudistuksen eri vaiheissa. Suoriteperusteinen valtionapujärjestelmä, joka on otettu käyttöön myös kansanopis- toissa, edustaa teknisen rationaliteetin mukaista käytäntöä weberiläisessä merkityksessä. Vapaan sivistystyön eri yksiköt pyritään tekemään yhteismitallisiksi keskenään sen sijaan, että eri yksiköt suhteutettaisiin niiden toimintaympäristöön.

Samanaikaisesti kun valtiollinen ohjaus on muuttunut on vapaan sivistystyön tekijöiden käsitys oman työnsä sisällöstä ja merkityksestä muuttumassa. Aulis Alasen kirjoitus "Tehokas palvelu aikuiskasvattajan ammattiideaalina" on hyvin kiinnostava yritys hahmottaa neljä erilaista tehtävänäkemystä aikuiskasvattajalle: 1) henkisen kasvun edistäminen, 2) tunnollinen toimen hoitaminen, 3) tehokas palvelu ja 4) kriittinen kasvunäkemys. Alasen näkemys ei perustu loppuun asti hiotulle typologialle, joka perustuisi täsmälliseen tutkimukseen. Avoimeksi hypoteesiksi ymmärrettynä, se avaa näkemyksen aikuiskasvattajan tehtävään tavalla, josta soisi keskusteltavan. Erityisesti Alanen on huolissaan tehokkaan palvelun periaatteen tunkeutumisesta vapaaseen sivistystyöhön. Kansalais- ja työväenopistojen kurssien suunnittelu alkaa seuraavilla kysynnän ja tarjonnan lakeja markkinoilla ja kansanopistojen "omavastuinen tehtävähaku" aiheuttaa opportunistista kysynnän seurailua. Nämä teemat ovat kehittelemisen arvoisia. Teoreettisesti tutkimusta olisi syvennettävä edelleen modernin kapitalistisen järjestelmän uusien piirteiden tutkimiseen ja empiiristä aineistoa olisi kerättävä koko aikuiskasvatuksen kentältä.

Aikuiskasvatuksen kehittäminen tieteenä edellyttää laaja-alaista otetta. Teorian kehittymiselle luo edellytyksiä myös Jukka Tuomiston "'Aikuiskasvatuksen kehittymisestä käytäntönä, oppiaineena ja tieteenä', Eero Pantzarin "Aikuiskasvatuksen kehittäminen ja tutkimus"' sekä 
Tero Aution "Kasvatuksesta ja sen tutkimuksesta". Tieto aikuiskasvatuksen yliopistollisesta traditiosta (Tuomisto) ja sen asemasta kansainvälisessä tutkimuksessa (Pantzar) auttavat tieteenalan kehittämistä. Tärkeää on kuitenkin pohtia, mitä sivistys nykyaikaisessa mielessä merkitsee. Vastakohdat luonnontieteen ja henkitieteen välillä sekä vapaan sivistystyön ja ammatillisen aikuiskoulutuksen välillä eivät ehkä kulje yksi yhteen. Näiden vastakohtien voittaminen ei ole helppo eikä yksinkertainen kysymys sen pa- remmin teoriassa kuin käytännössäkään, mutta siihen tulisi pyrkiä. Siitäkin huolimatta, että ammatillisessa aikuiskoulutuksessa pyrkimys tekniseen rationaliteettiin on mitä ilmeisin. Kosti Huuhkan "'Kansansivistystyöstä aikuiskoulutukseen" ja Olavi Alkion "Kansansivistystyön myytistä aikuiskoulutuksen kokonaisuuteen"' kuvastuvat hyvin tämän problematiikan eräitä puolia. Kysymystä ei tulisi asettaa ammatillisen koulutuksen tunkeutumisena vapaaseen sivistystyöhön, vaan myös ammatillisen aikuiskas- vatuksen vapauttamisena ahtaasta utilitarismista.

Harvan juhlakirjassa on myös kaksi artikkelia, joissa tuodaan aikuiskasvattajille kaksi käytännön haastetta: vanhempainkasvatus ja rauhankasvatus (Ritva JakkuSihvonen ja Helena Kekkonen) - teemoja, joista molemmat kirjoittajat ovat toisissa yhteyksissäkin kirjoittaneet. Etenkin rauhankasvatuksen merkitystä sekä vapaassa että ammatillisessa aikuiskasvatuksessa tulisi korostaa.

Pekka Kalli 